\title{
HUBUNGAN KECUKUPAN GIZI DENGAN STATUS GIZI BALITA
}

\author{
Imelda Feneranda Seravia Tambi \\ Jurusan Keperawatan, STIKES Dirgahayu Samarinda \\ J1. Pasundan Nomor 21 Kelurahan Jawa Kecamatan Samarinda Ulu \\ Kota Samarinda Kalimantan Timur Kode Pos 75122 \\ email: imeldafeneranda@gmail.com
}

\begin{abstract}
Nutritional adequacy needed by all group of ages, one of them is toddlers and nutritional adequacy can be illustrated through nutritional status. Toolders have a significant need for nutrients that support growth and provide energy. The design of this study was correlation study. Population of this study was toddlers in IHC Sedap Malam Bumiarjo RW 05. The technique was used random sampling of 35 respondents. Data were collected by filling the 24-hour food recall observation sheet and measuring the anthropometric of height and weight. From the statistic test result of Rank Spearman used the SPSS 16 program, it showed that $\mathrm{p}=0,011, \mathrm{p}<0,05$ then $\mathrm{H}_{0}$ was rejected, with $\mathrm{rs}+0,425$ which means that there is a moderate positive strength relationship between nutritional adequacy and nutritional status in toddlers. Nutrition have an important role to improve the nutritional status. Therefore, the researcher suggests to improve IHC programs in the field of nutrition such as healthy toddler competitions dan counseling.
\end{abstract}

Key words: nutritional adequacy, nutritional status, toddlers

\section{PENDAHULUAN}

Balita adalah anak yang berusia 15 tahun (Pohan, 2006:234). Anak balita juga merupakan kelompok umur yang rawan gizi dan rawan penyakit. Kelompok ini yang merupakan kelompok yang paling menderita akibat gizi kurang kalori protein (KKP) dan jumlahnya dalam populasi besar. Gizi seimbang diperlukan oleh semua kelompok umur, salah satunya adalah balita (Proverawati, 2009). Balita memiliki kebutuhan yang signifikan untuk nutrisi yang mendukung pertumbuhan dan menyediakan energi. Pemenuhan status gizi balita dapat digambarkan melalui status gizi. Status gizi anak usia bawah lima tahun (balita) merupakan salah satu indikator pembangunan kesehatan (Yendra, 2009). Fenomena yang ditemukan peneliti di wilayah Posyandu Sedap Malam RW 05 Bumiarjo Kelurahan Sawunggaling Kecamatan Wonokromo Surabaya adalah masih terdapat balita dengan kartu menuju sehat (KMS) memperlihatkan di bawah garis merah (BGM), dibawah garis titik-titik (BGT), di atas garis hijau, penampilan fisik balita yang telihat kurus, tidak segar, tampak sangat gemuk selain itu masih terlihat orang tua atau pengasuh yang memberikan makan pada balita dengan 
menyajikan kuah sayur dan kerupuk saja sebagai pengganti lauk pauk, kebiasan jajan balita juga masih terlihat. Jajan pada balita juga merupakan hal yang biasa diberikan oleh orang tua meskipun dimulai pada pagi hari.

Data survei awal yang dilakukan peneliti pada tanggal 14 Desember 2012, dengan melakukan pengukuran berat badan dan tinggi badan balita di Posyandu RW 05 Bumiarjo Kelurahan Sawunggaling Kecamatan Wonokromo Surabaya, menunjukan 10 balita ditemukan 2 balita dengan status gizi kurus, 8 balita dengan status gizi normal berdasarkan hasil perhitungan menggunakan $\mathrm{Z}$ score. Pada saat Posyandu peneliti mewawancarai ibu mengenai kebiasaan pemberian makanan, dimana 1 ibu balita mengatakan makanan yang biasa diberikan berupa nasi dan kuah bakso, 1 ibu lainnya terlihat sedang memberikan makanan kepada balitanya dengan menggunakan nasi dan sedikit ikan goreng saja. Ibu dengan balita yang mengalami BGM mengatakan sudah berupaya memberi makan sesuai dengan kesukaan anak saja untuk menambah nafsu makan. Pada saat Posyandu juga balita tampak lebih memilih jajan daripada makanan tambahan yang telah disediakan.

Faktor-faktor yang mempengaruhi status gizi meliputi faktor langsung yaitu disebabkan oleh kurangnya konsumsi makanan dan adanya penyakit infeksi. Konsumsi makanan dalam keluarga dipengaruhi jumlah dan jenis pangan yang dibeli, pemasukan, distribusi dalam keluarga dan kebiasaan makan secara perorangan. Konsumsi juga tergantung pada pendapatan, agama, adat istiadat dan pendidikan keluarga yang bersangkutan. Sedangkan penyebab tidak langsung adalah ketahanan pangan (Adriani, 2012). Waktu yang dipergunakan ibu rumah tangga untuk mengasuh anak merupakan salah satu faktor yang dapat mempengaruhi status gizi anak. Sebagai gate keeper, yaitu orang yang menentukan bahan makanan yang akan dibeli, dimasak dan disiapkan, ibu memainkan peranan penting dalam menatalaksanakan pangan/makanan bagi anak balita (Istiany, 2012:133). Anak balita juga merupakan kelompok umur yang rawan gizi dan rawan penyakit (Notoatmodjo, 2011:233). Kurang gizi berakibat anak mudah diserang berbagai penyakit (Notoatmodjo, 2011:245). Anak akan mengalami berat badan berlebihan (overweight) dan kelebihan lemak dalam tubuh apabila selalu makan dalam porsi besar dan tidak diimbangi dengan aktivitas yang seimbang (Febri, 2008:14). Status gizi pada masa balita perlu mendapatkan perhatian yang serius dari para orang tua, kerena kekurangan gizi pada masa ini akan menyebabkan kerusakan yang irreversible (tidak dapat dipulihkan) (Proverawati, 2009:135).

Tujuan dari penelitian ini adalah menganalisis hubungan antara kecukupan gizi dengan status gizi balita di Posyandu Sedap Malam RW 05 Bumiarjo Kelurahan Sawunggaling Kecamatan Wonokromo Surabaya.

\section{METODE}

Desain penelitian yang digunakan adalah studi korelasi. Dalam penelitian ini variabel bebas yang digunakan adalah kecukupan gizi balita dan variabel terikat adalah status gizi balita. Populasi dalam penelitian ini adalah jumlah balita yang 
hadir pada posyandu balita bulan Maret 2013 yaitu sejumlah 77 balita yang memenuhi kriteria inklusi : balita yang hadir pada Posyandu pada bulan Maret 2013, ibu balita/pengasuh dan balita yang bersedia menjadi responden, ibu balita/ pengasuh yang bisa membaca dan menulis. Sampel pada penelitian ini adalah 35 sampel.

Teknik pengambilan sampel dalam penelitian ini adalah dengan mgnggunakan simple random sampling. Teknik simple random sampling dilakukan terhadap masing-masing wilayah Sedap Malam 1, Sedap Malam 2, dan Sedap Malam 3. Penentuan responden dari masing-masing wilayah Sedap Malam dilakukan dengan membuat undi.

Penelitian kecukupan gizi dilakukan pada tanggal 13-14 April 2013 di rumah masing-masing responden. Penelitian status gizi pada balita dilaksanakan pada saat penimbangan dan pengukuran tinggi badan pada tanggal 15 April 2013 di Posyandu Sedap Malam RW 05 Bumiarjo Kelurahan Sawunggaling Kecamatan Wonokromo Surabaya. Pada penelitian ini peneliti melakukan food recall dengan menggunakan lembar observasi food recall, sedangkan pada status gizi peneliti melakukan pengukuran antropometri berat badan dan tinggi badan dengan menggunakan dacin dan pengukuran tinggi badan menggunakan microtoise.

Scoring dilakukan dengan menggunakan rumus sebagai berikut: perhitungan angka kecukupan gizi (AKG) untuk individu dengan membandingkan tingkat konsumsi energy dengan nilai $\mathrm{AKG}$ individu tersebut, setelah itu klasifikasi tingkat konsumsi dibagi mejadi empat dengan cut of points masing-masing sebagai berikut: baik ( $\geq 100 \%$ AKG), sedang (80-99\% AKG), kurang (70-80\% AKG), defisit $(<70 \% \quad$ AKG $)$. Perhitungan untuk status gizi menggunakan rumus $\mathrm{Z}$ score berdasarkan berat badan/tinggi badan. Pada penelitian ini menggunakan alat bantu komputer dengan anthropometric calculator yang terdapat pada perangkat lunak WHO Anthro.

\section{HASIL DAN PEMBAHASAN \\ Hasil Penelitian}

Tabel 1. Karekteristik Responden

\begin{tabular}{lll}
\hline Kriteria & N & \% \\
\hline Usia & & \\
$1-3$ tahun & 28 & $80 \%$ \\
4-5 tahun & 7 & $20 \%$ \\
$\begin{array}{l}\text { Pendidikan Ibu } \\
\text { SMP }\end{array}$ & 3 & $8.6 \%$ \\
SMA & 24 & $68.9 \%$ \\
Perguruan Tinggi & 8 & $22.9 \%$ \\
Pengasuh Responden & & \\
Orang Lain & 5 & $14 \%$ \\
$\begin{array}{l}\text { Anggota Keluarga (nenek) } \\
\text { Ibu }\end{array}$ & 6 & $17 \%$ \\
$\begin{array}{l}\text { Penghasilan Keluarga } \\
\text { < Rp.1.000.000 }\end{array}$ & 24 & $69 \%$ \\
$\begin{array}{l}\text { Rp.1.000.000-2.500.000 } \\
\text { > Rp.2.500.000 }\end{array}$ & 7 & $20 \%$ \\
Kebiasaan Mengkonsumsi & 19 & $54.3 \%$ \\
Susu Formula & 9 & $25.7 \%$ \\
Tidak Mengkonsumsi & & \\
Konsumsi & 3 & $8.6 \%$ \\
& 32 & $91.4 \%$ \\
\hline
\end{tabular}

Tabel 2. Data Khusus

\begin{tabular}{lll}
\hline Kriteria & N & \% \\
\hline Kecukupan Gizi & & \\
Kurang & 1 & $3 \%$ \\
Sedang & 13 & $37 \%$ \\
Baik & 21 & $60 \&$ \\
Status Gizi & & \\
Kurus & 1 & $3 \%$ \\
Normal & 29 & $83 \%$ \\
Gemuk & 5 & $14 \%$ \\
\hline
\end{tabular}


Tabel 3. Tabulasi silang antara

\section{Kecukupan Gizi dengan Status Gizi}

Balita

\begin{tabular}{lllllllll}
\hline \multirow{2}{*}{$\begin{array}{c}\text { Kecukupan } \\
\text { Gizi }\end{array}$} & \multicolumn{4}{c}{ Status } & \multicolumn{2}{c}{ Gizi } & \multirow{2}{*}{ Total } \\
\cline { 2 - 7 } & \multicolumn{1}{c}{ Kurus } & \multicolumn{2}{c}{ Normal } & \multicolumn{2}{c}{ Gemuk } & & \\
\cline { 2 - 8 } & F & $\%$ & F & $\%$ & F & $\%$ & F & $\%$ \\
\hline Kurang & 1 & 100 & 0 & 0 & 0 & 0 & 1 & 100 \\
Sedang & 0 & 0 & 13 & 100 & 0 & 0 & 13 & 100 \\
Normal & 0 & 0 & 16 & 76.2 & 5 & 23.8 & 21 & 100 \\
Total & 1 & 2.9 & 29 & 82.9 & 5 & 14.3 & 35 & 100 \\
\hline
\end{tabular}

Tabel 4. Non Parametic Correlation

\begin{tabular}{|c|c|c|c|}
\hline \multicolumn{2}{|c|}{ Spearman's rho } & \multirow{2}{*}{$\begin{array}{l}\begin{array}{l}\text { status } \\
\text { gizi }\end{array} \\
1.000\end{array}$} & \multirow{2}{*}{$\begin{array}{l}\text { kecukupan } \\
\text { gizi }\end{array}$} \\
\hline status gizi & $\begin{array}{l}\text { Correlation } \\
\text { Coefficient }\end{array}$ & & \\
\hline \multirow{4}{*}{$\begin{array}{l}\text { kecukupan } \\
\text { gizi }\end{array}$} & $\begin{array}{l}\text { Sig. } \\
\text { tailed) }\end{array}$ & & .011 \\
\hline & $\mathrm{N}$ & 35 & 35 \\
\hline & $\begin{array}{l}\text { Correlation } \\
\text { Coefficient }\end{array}$ & $.425^{*}$ & 1.000 \\
\hline & $\begin{array}{l}\text { Sig. } \\
\text { tailed) }\end{array}$ & .011 & - \\
\hline
\end{tabular}

Berdasarkan tabel 3 dapat dilihat hubungan antara kecukupan gizi dengan status gizi pada balita di Posyandu Sedap Malam RW 05 Bumiarjo Kelurahan Sawunggaling Kecamatan Wonokromo Surabaya menunjukan bahwa dari 21 responden yang memiliki kecukupan gizi normal diantaranya 16 dengan status gizi normal (76.2\%) dan 5 responden dengan status gizi gemuk (23.8\%). Dari 13 responden memiliki kecukupan gizi sedang dan status gizi normal. Dan dari 1 responden (100\%) yang memiliki kecukupan gizi kurang memiliki status gizi kurus. Uji hipotesis dilakukan dengan menggunakan dengan uji Rank Sperman dan dianalisis dengan menggunakan Program SPSS 16 untuk menentukan hubungan antara kecukupan gizi dengan status gizi pada balita.
Berdasarkan analisis korelasi dari Rank Spearman, ditemukan $\mathrm{p}=0,011$ atau $\mathrm{p}<$ 0,05 maka $\mathrm{H}_{0}$ ditolak, serta memilik rs +0.425 .

Hasil penelitian pada variabel kecukupan gizi didapatkan balita yang masuk dalam kecukupan gizi baik yaitu sebanyak 21 orang $(60 \%)$, bila ditinjau dari segi pendidikannya 13 responden (61.9\%) memiliki pendidikan terakhir di Perguruan Tinggi dan pada kecukupan gizi sedang didapatkan 10 orang (76.9\%) berpendidikan terakhir di SMA. Menurut Adriani (2012) seorang ibu dengan pendidikan yang tinggi akan dapat merencanakan menu makanan yang sehat dan bergizi. Menurut peneliti ada kesesuaian antara fakta dan teori, bahwa responden yang memiliki pendidikan di Perguruan Tinggi dan SMA dapat menunjukan juga memiliki pengetahuan yang baik sesuai dengan pendidikannya, sehingga didapatkan kecukupan gizi balitanya memasuki kategori baik. Orang tua dengan balita dalam kategori sedang diharapkan juga dapat meningkatkan kecukupan gizi balita agar lebih mengarah pada kecukupan gizi baik dan menghindari pada kecukupan gizi kurang atau bahkan defisit. Selain itu dengan pendidikan yang dimiliki oleh orang tua responden pada kecukupan gizi sedang dapat memudahkan penyampaian informasi oleh tenaga kesehatan mengenai cara meningkatkan pemenuhan kecukupan gizi ke arah yang lebih baik, dengan demikian balita tidak selalu berada pada kecukupan gizi yang sedang. Melalui pengetahuan yang baik pula orang tua dapat menyadari pentingnya pemberian makanan tambahan yang dapat melengkapi kebutuhan gizi untuk balita. 
Pada kecukupan gizi dengan kategori kurang didapatkan pada 1 responden (3\%) dengan hasil observasi food recall selama 2 x 24 jam yaitu 628,2065 kalori. Lebih muda umur anak maka lebih banyak makanan yang diperlukan untuk tiap kilogram berat badannya (Adriani, 2012). Menurut Widya Karya Nasional Pangan dan Gizi (1998) yang dikutip oleh Devi (2010) kebutuhan energi berdasarkan AKG pada usia 1-3 tahun adalah 1000 kkal. Menurut Fadila (2012) asupan dibawah nilai AKG tidak selalu berarti tidak cukup, namun makin jauh dibawah nilai tersebut resiko untuk memperoleh asupan yang tidak cukup, meningkat. Pemberian makanan bergizi mutlak dianjurkan untuk anak melalui peran ibu atau pengasuhnya (Istiany, 2013:133). Menurut peneliti ada kesesuaian antara fakta dan teori, bahwa pada responden dengan umur yang berada dalam 1-3 tahun seharusnya mendapatkan 1000 kkal dan apabila mendapatkan asupan yang terlampau jauh di bawah dari AKG yang dianjurkan, maka dapat masuk dalam kategori kecukupan gizi kurang. Pilihan makanan yang berkualitas sangat dipengaruhi oleh orang tua, karena dengan pilihan makanan yang berkualitas dan mengandung nilai gizi yang tinggi akan membawa balita pada pemenuhan kecukupan gizi yang baik, sehingga dapat menunjang pertumbuhan yang optimal bagi balita pada awal pertumbuhannya. Perbaikan dalam masalah ini salah satunya dapat dilakukan melalui penyuluhan kepada orang tua dengan memberikan informasi sehingga dapat mempengaruhi pilihan makanan orang tua kepada balita. Peranan tenaga kesehatan dalam penyuluhan mengenai gizi ini sangatlah diperlukan, meskipun sudah dilakukan akan tetapi perlunya peningkatan dan perbaikan dengan memperhatikan metode penyuluhan. Metode penyuluhan yang baik dapat mempengaruhi informasi yang disampaikan dan memungkinkan ibu-ibu atau pengasuh dapat mengerti mengenai informasi yang disampaikan. Penyuluhan mengenai gizi dapat dilakukan pada kegiatan ibu-ibu PKK yang sudah ada di RW 05 Bumiarjo dan di luar kegiatan Posyandu balita. Kegiatan lainnya yang dapat meningkatkan motivasi orang tua mengenai kecukupan gizi juga dapat dilakukan melalui mengembangkan kegiatan lomba balita sehat dengan menggunakan observasi food recall sebagai salah satu penilaiannya.

Pada penelitian mengenai status gizi didapatkan 29 responden (83\%) dengan status gizi normal dan bila ditinjau dari pendidikan orang tua sebanyak 20 orang berpendidikan terakhir SMA (69\%). Ditinjau dari penghasilan keluarga 15 responden (52\%) berpenghasilan antara Rp. 1.000.000-2.500.000. Menurut Adriani (2012) salah satu yang mempengaruhi status gizi adalah penyebab langsung dimana konsumsi juga tergantung pada pendapatan dan pendidikan keluarga yang bersangkutan. Pendidikan formal sangat diperlukan oleh ibu rumah tangga dalam meningkatkan pengetahuan dalam upaya mengatur dan mengetahui hubungan antara makanan dan kesehatan atau termasuk kebutuhan zat gizi bagi anggota keluarganya. Pendapatan keluarga yang memadai anak menunjang tumbuh kembang anak, karena orang tua dapat menyediakan semua kebutuhan 
anak baik yang primer seperti makanan maupun yang sekunder. Menurut peneliti ada kesesuaian antara fakta dan teori, bahwa dengan adanya pendidikan yang baik diharapkan juga orang tua memiliki pengetahuan yang baik sehingga dapat menyajikan makanan yang mengandung nilai gizi tinggi dan menarik. Pengetahuan orang tua yang diperoleh dari pendidikan yang tinggi sangat diperlukan dalam memantau status gizi balitanya secara berkala, sehingga dapat mempertahankan status gizi normal ataupun meningkatkan status gizi balitanya. Penghasilan yang cukup di dalam keluarga dapat menunjang orang tua untuk dapat menyediakan makanan yang mengandung nilai gizi yang dibutuhkan baik dari segi kualitas maupun kuantitas yang dapat mengarahkan pada status gizi yang normal.

Pada responden dengan status gizi kurus yaitu 1 responden (3\%) dan pengasuh responden adalah anggota keluarga (nenek) (100\%). Waktu yang dipergunakan ibu rumah tangga untuk mengasuh anak merupakan salah satu faktor yang dapat mempengaruhi status gizi anak. Sebagai gate keeper, yaitu orang yang menentukan bahan makanan yang akan dibeli, dimasak dan disiapkan, ibu memainkan peranan penting dalam menatalaksanakan pangan/makanan bagi anak balita. Tanggung jawab ibulah seorang anak mendapatkan asupan (intake) makanan yang bergizi, sesuai dengan kebutuhan tubuh. Kekurangan gizi merupakan akibat dari kebiasaan hidup yang kurang memikirkan nilainilai gizi (Istiany, 2013:133). Menurut Crepinsek dan Bursten (2004) yang dikutip oleh Food Assitance and
Nutrition Research Program Staff (2007) ibu yang bekerja kurang berpartisipasi dalam perencanaan makan, belanja bahan makanan, persiapan makanan dan anak-anak dari ibu yang bekerja dengan waktu penuh lebih cenderung untuk melewatkan makan pagi, lebih mengandalkan sumber makanan yang jauh dari rumah. Salah satu pesan gizi seimbang oleh Depkes RI (2000) yang dikutip oleh Adriani (2012) adalah kebiasaan makan pagi yang membantu balita untuk memenuhi kebutuhan gizinya sehari-hari. Makan pagi secara teratur setiap hari dalam jumlah yang cukup amat penting untuk memelihara ketahanan fisik, mempertahankan daya tahan tubuh. Apabila anak tidak dibiasakan makan pagi akan mengalami kekurangan tenaga, badan menjadi lesu. Menurut peneliti terdapat kesesuaian antara fakta dan teori, bahwa dengan kurangnya partisipasi ibu yang bekerja pada responden ini tidak terlibat secara langsung mengenai pilihan makanan yang bergizi dan menyerahkan semua pengaturan makan pada anggota keluarga yang mengasuh dalam hal ini responden diasuh oleh nenek, akan menyebabkan perubahan ketahanan fisik yang tidak terpelihara. Pengasuhan yang membiarkan balita mengkonsumsi makanan yang nilai gizinya rendah pada akhirnya akan mengakibatkan status gizi kurus. Ibu atau pengasuh perlu menyadari makanan yang harus dikonsumsi pada usia balita dan hendaknya memberikan contoh yang baik yaitu salah satunya membiasakan makan pagi. Meskipun balita tidak diasuh oleh ibu setiap saat akan tetapi mengenai kualitas pilihan makanan harus tetap diterapkan kepada balitanya 
sehingga dapat menunjang peningkatan asupan gizi yang lengkap dan tepat dengan demikian akan memberikan masukan pula untuk status gizi balita tersebut ke arah yang lebih baik.

Pada kategori status gizi gemuk ditemukan 5 orang responden (23.8\%). Bila ditinjau dari pendidikan orang tua terdapat 2 responden yang berpendidikan terakhir SMP (40\%) dan bila ditinjau dari kebiasaan mengkonsumsi susu formula sebagai makanan tambahan dari 5 orang responden sebanyak $100 \%$. Anak akan mengalami berat badan berlebihan (overweight) dan kelebihan lemak dalam tubuh apabila selalu makan dalam porsi besar dan tidak diimbangi dengan aktivitas yang seimbang (Febri, 14:2008). Menurut Adriani (2012) anak yang meminum susu dalam botol, biasanya tidak dapat menghitung jumlah masukan makanan pada balita, bahkan para orang tua cenderung memberikan perawatan balita dengan membuat susunya lebih kental, sehingga melebihi porsi yang dibutuhkan balita. Pada penelitian ini data yang ditemukan oleh peneliti melalui food recall, takaran susu dan frekuensi pemberian susu formula kepada balita sangatlah tinggi sehingga ditemukan ketidakseimbangan antara pemberian susu formula dengan makanan utama yang dikonsumsi. Menurut peneliti ada kesesuaian antara fakta dan teori bahwa pada pemberian susu formula yang berlebih tanpa memperhatikan takaran dan membiasakan balita lebih kenyang dengan susu tersebut atau meminumnya sebagai pengganti makanan utama, serta dengan aktivitas fisik yang terbatas dimana hanya berupa menonton televisi dan bermain games yang dijumpai pada responden dapat mengakibatkan balita menjadi obesitas dan diketegorikan status gizi gemuk. Perilaku dan pengetahuan orang tua/pengasuh berperan penting dalam perbaikan maupun pencegahan pada masalah yang akan berlanjut akibat dari obesitas sampai remaja dan dewasa sehingga diharapkan dapat memberikan susu formula dengan baik dan benar secara kualitas dan kuantitas serta mengarahkan balita untuk melakukan aktivitas yang seimbang.

Berdasarkan data hasil penelitian didapatkan $16(76.5 \%)$ balita dengan kecukupan gizi baik diikuti dengan status gizi normal dan 13 (100\%) balita dengan kecukupan gizi sedang diikuti dengan status gizi normal. Berdasarkan uji yang dilakukan ditemukan $\mathrm{p}=0,011$ atau $\mathrm{p}<0,05$ maka $\mathrm{H}_{0}$ ditolak hal ini menunjukan bahwa ada hubungan antara kecukupan gizi dengan status gizi balita, serta memilik rs $+0,425$ berarti ada hubungan positif dengan kekuatan sedang. Menurut Adriani (2013) penyebab tidak langsung yang mempengaruhi status gizi salah satunya adalah food utilization yaitu penggunaan pangan untuk kebutuhan hidup sehat yang meliputi kebutuhan energi dan gizi, air dan kesehatan lingkungan. Status gizi (nutrition status) adalah ekspresi dari keadaan keseimbangan dalam bentuk variabel tertentu atau perwujudan dari nutriture dalam bentuk variabel tertentu (Supariasa, 2012:24). Menurut peneliti ada kesesuaian antara fakta dan teori, bahwa kecukupan gizi yang merupakan suatu kecukupan rata-rata zat gizi setiap hari menurut golongan umur, jenis kelamin, ukuran tubuh pada balita dapat mempengaruhi status gizi balita. 
Berdasarkan nilai koefisien korelasi yang dihasilkan dapat dikatakan berbanding lurus dan positif dimana semakin baik kecukupan gizi balita maka akan menunjang pula status gizi yang normal pada balita, dan sebaliknya dengan semakin kurang kecukupan gizi balita akan mempengaruhi status gizi yang tidak baik yaitu dalam kategori kurus atau bahkan sangat kurus. Kecukupan gizi dan status gizi balita perlu diperhatikan oleh orang tua atau pengasuh balita agar dapat menunjang kesehatan balitanya,

\section{SIMPULAN DAN SARAN}

Berdasarkan hasil penelitian dapat disimpulkan bahwa: Terdapat lebih dari $50 \% \quad(60 \%)$ responden dengan kecukupan gizi balita baik, terdapat sebagian besar $(83 \%)$ responden dengan status gizi balita normal. Ada hubungan yang positif sedang antara kecukupan gizi dengan status gizi balita di Posyandu Sedap Malam RW 05 Bumiharjo Kelurahan Sawunggaling Kecamatan Wonokromo Surabaya.

Diharapkan kepada pengurus RW 05 dan para kader Posyandu melalui kerjasama dengan petugas Puskesmas Jagir agar dapat meningkatkan program dalam bidang gizi secara berkala seperti: penyuluhan pada kegiatan ibu-ibu PKK dan diluar jadwal Posyandu balita dengan memperhatikan metode penyuluhan dengan baik, mengembangkan kegiatan lomba balita sehat dengan menggunakan observasi food recall sebagai salah satu penilaiannya, serta kegiatan yang berhubungan dengan aktivitas fisik kepada balita terutama balita yang mengalami obesitas.

\section{DAFTAR RUJUKAN}

Adiningsih, Sri. (2010). Waspadai Gizi Balita Anda. Jakarta: PT. Elex Media Komputindo

Adriani, Merryana dan Bambang Wirjatmadi. (2012). Pengantar Gizi Masyarakat. Jakarta: Kencana Prenada Media Group (2012). Peranan Gizi dalam Siklus Kehidupan. Jakarta: Kencana Prenada Media Group

Anggraeni, Adisty Cynthia. (2012). Asuhan Gizi; Nutritional Care Process. Yogyakarta: Graha Ilmu Arikunto, Suharsimi. (2010). Prosedur Penelitian Suatu Pendekatan Praktik. Jakarta: Rhineka Cipta

Arisman. (2007). Gizi dalam Daur Kehidupan. Jakarta: EGC

Cerika, Rismayanthi. (2012). Perhitungan Nilai Kalori Bahan Makanan.

(http://staf.uny.ac.id/sites/defalut/fi les/perhitunganilai Kalori Bahan Makan. Compatibility Mode.pdf. Diakses tanggal 9 Februari 2013:22.49)

DCN, Usman. (2012). WHO Anthro 2005. (http://smr.web.id. Diakses tanggal 30 Januari 2013:07.44)

Devi, Nirmala. (2010). Nutrition and Food : Gizi untuk Keluarga. Jakarta: Kompas

Duggan, Christopher. et al. (2003). Nutrition in Pediatrics. Fourth Edition Hamilton: BC Decker Inc Eveline, PN dan Nanang Djamaludin. (2010). Panduan Pintar Merawat Bayi dan Balita. Jakarta: Wahyu Media 
Fadila, Ila. (2012). Gizi dan Kesehatan Keluarga.

(http://ut.ac.id/html/suplemen/luh t4449/new_page_2.htm. Diakses tanggal 10 Februari 2013:20.10)

Febry, Ayu Bulan. (2008). Buku Pintar Menu Balita. Jakarta: PT. Wahyu Media

Food Assitance and Nutrition Research Program Staff. (2007). Informing Food and Nutrition Assitance Police. US :United States Department of Agriculture

Hidayat, A. Aziz Alimul. (2010). Metode Penelitian Kesehatan Paradigma Kuantitatif. Surabaya: Health Books Publishing (2008).

Pengantar Ilmu Kesehatan Anak untuk Kebidanan. Jakarta: Salemba Medika

$$
\text { (2007). Riset }
$$
Keperawatan dan Teknik Penulisan Ilmiah. Ed. 2. Jakarta: Salemba Medika

2005).

Pengantar Ilmu Kesehatan Anak 1. Jakarta: Salemba Medika

Irianto, Kus dan Kusno Waluyo. (2004). Gizi dan Pola Hidup Sehat. Edisi 1.Bandung: Yrama Widya

Istyani, Ari dan Ruslianti. (2013). Gizi Terapan. Bandung: PT. RemajaRosdakarya

Kemetrian Kesehatan RI. (2011). Standar Antropometri Penilaian Status Gizi. Jakarta: Direktorat Jendral Bina Gizi dan Kesejahteraan Ibu dan Anak, Direktorat Bina Gizi

Marmi, dan Kukuh Rahardjo. (2012). Asuhan Neonatus, Bayi, Balita dan
Anak Prasekolah. Yogyakarta: Pustaka Pelajar

Muaris, Haris. (2006). Bekal Sekolah untuk Anak Balita. Jakarta: PT. Gramedia Pusaka Utama

Nazir, Mohamad. (2003). Metode Penelitian. Jakarta: Ghalia Indonesia

Notoatmodjo, Soekidjo. (2011). Kesehatan Masyarakat Ilmu dan Seni. Jakarta: Rineka Cipta (2010).

Metodologi Penelitian Kesehatan. Jakarta: Rineka Cipta

Nursalam. (2003). Konsep dan Penerapan Metodologi Penelitian Ilmu Keperawatan. Ed. 2. Jakarta: Salemba medika

Pohan, Imbalo S. (2006). Jaminan Mutu Layanan Kesehatan Dasar-Dasar Pengertian dan Penerapan. Jakarta: EGC

Preedy, Victor R. (2012). Handbook of Anthropometry Physical Measures Of Human Form in Health and Disease. Vol 1. Parts 1-6. London: Springer

Proverawati, Atikah dan Siti Asfuah. (2009). Buku Ajar Gizi untuk Kebidanan. Yogyakarta: Nuha Medika

Purwanto, Heri. (1995). Pengantar Statistik Keperawatan. Jakarta: EGC

Samour, Queen and Kathy King. (2012). Pediatricts Nutrition. Fourth Edition. USA: Jonas \& Bartlett Learning

Sandjaja. et al. (2009). Kamus Gizi Pelengkap Kesehatan Keluarga. Jakarta: Kompas 
Setiadi. (2007). Statistik untuk Penelitian. Bandung: CV Alfabeta

Sharlin, Judith and Dari Edelstein. (2011). Essentials of Life Cycle Nutrition. London: Jonas and Bartlett's

Sugiyono. (2012). Statistika untuk Penelitian. Jakarta: IKAPI

Supriasa, I Dewa Nyoman. (2012). Penilaian Status Gizi. Jakarta: EGC

Tim Penulis Fakultas Ekonomi Universitas Indonesia. Editor: Melvi Yendra. (2009). Indonesia Economic Outlook 2010. Jakarta: Grasindo

World Health Organization. (2009). WHO Anthro For Personal Computers Manual. (http://gizi.depkes.go.id. Diakses tanggal 30 Januari 2013:19.25)

World Health Organization and UNICEF. (2009). WHO Child Growth Standars and The Identification of Severe Acute Malnutrition in Infans and Children. Geneva: WHO Press

World Health Organization. (2006).

Standard Deviation of Anthropometric.

(http://www.who.int/bulletin/volu mes/85/6/06-034421. Diakses tanggal 24 Januari 2013:1.03) 